\title{
Depositional Setting of Sandstones from the Oligocene-Miocene Ogwashi-Asaba Formation, Niger Delta Basin, Nigeria: Evidence from Grain Size Analysis and Geochemistry
}

\author{
Ejeh O. Innocent, Akpoborie I. Anthony ${ }^{*}$, Etobro, A.A. Israel \\ Department of Geology, Delta State University, Nigeria
}

Copyright (C) 2015 Horizon Research Publishing All rights reserved.

\begin{abstract}
Field observations at freshly exposed quarry sites, grain size analysis, mass spectrometry and statistical methods have been used to determine the depositional setting of sandstones from the Oligocene-Miocene Ogwashi-Asaba Formation. Some of the sandstones are ferruginized and indurated; others are friable, cross-bedded, non-ferruginized, white to yellow to reddish brown on weathering, and show top/bottom mantled pebbles. Textural examination indicates that the sandstones range from fine to coarse sands, with graphic mean grain size of -0.3 to $2.13 \phi$. Standard deviation ranges from 0.62 to $1.52 \phi$ and implies moderately sorted to poorly sorted sediments. Textural indices suggest that most of the sediments were deposited under fluvio-deltaic to shallow marine environment by fluvial and beach processes adjacent to a near shore whirlpool agitating turbidity conditions. Major elemental oxides show $\mathrm{SiO}_{2}$ content $>71 \%$ with extreme depletion of mobile oxides such as $\mathrm{Na}_{2} \mathrm{O}, \mathrm{CaO}$ and the ferromagnesian minerals through weathering and sedimentary processes.
\end{abstract}

Keywords Niger Delta Basin, Ogwashi-Asaba Formation, Sandstones, Geochemistry, Depositional setting

\section{Introduction}

Sandy sedimentary successions are invaluable parts of sedimentary basins earth wide and, these sequences constitute potential aquifers and petroleum reservoirs. The sedimentary deposits of the Niger Delta Basin are thus well known for their rich aquifers and petroleum potential. The lignite bearing Ogwashi-Asaba Formation [1] is almost everywhere masked by superficial cover in the area west of the River Niger and exposures are few. An approximately $10 \mathrm{~m}$ thick succession of fine to coarse-grained sandstones (ferruginous and non-ferruginous), pebble and conglomeritic sandstone at the Ibusa quarry site and surrounding areas (Fig.1) has now provided a unique opportunity for close in situ examination of the sedimentary pile.

Previous work on the Ogwashi-Asaba Formation include a localized hydrogeological assessment of its shallow aquifer horizon [1], the geochemical assessment of the lignites that occur in it by Ogala [2] and Bassey and Eminue [3] who use evidence from petrography, geochemical and sedimentological data obtained from a range of sedimentary rock types in the formation to infer that the sandstones of the formation are texturally, chemically and mineralogically immature.

The objective of this present work is to attempt to infer depositional settings of the formation using sedimentological and geochemical attributes of the sandstone lithologic unit. These attributes include various textural characteristics and analyses and interpretation of related statistical indices.

Textural characteristics constitute fundamental descriptive measure of sediments and sedimentary rocks. The focus of textural studies is to employ graphical, moments and statistical methods to discriminate between sedimentary successions based on environment of deposition [4, 5 and 6]. Bivariate plots between various statistical grain size parameters have also been successfully used for distinction of such environments $[7,8]$.

Thus it has been shown [7] that plots of skewness against mean - phi value of a distribution reveal clear signatures of dune sands, ocean beach sands and the lake beach sands.

Sahu [9] has also used Linear Discriminant Functions (LDF) to discover the relationship between variances exhibited by statistical parameters. Furthermore, it has been shown that as long as the bulk composition of the rock is not totally altered by weathering, major element data provide useful insights in the geochemical analysis of sandstone depositional environments $[10,11,12]$. These tools have been deployed and used in this present study. 


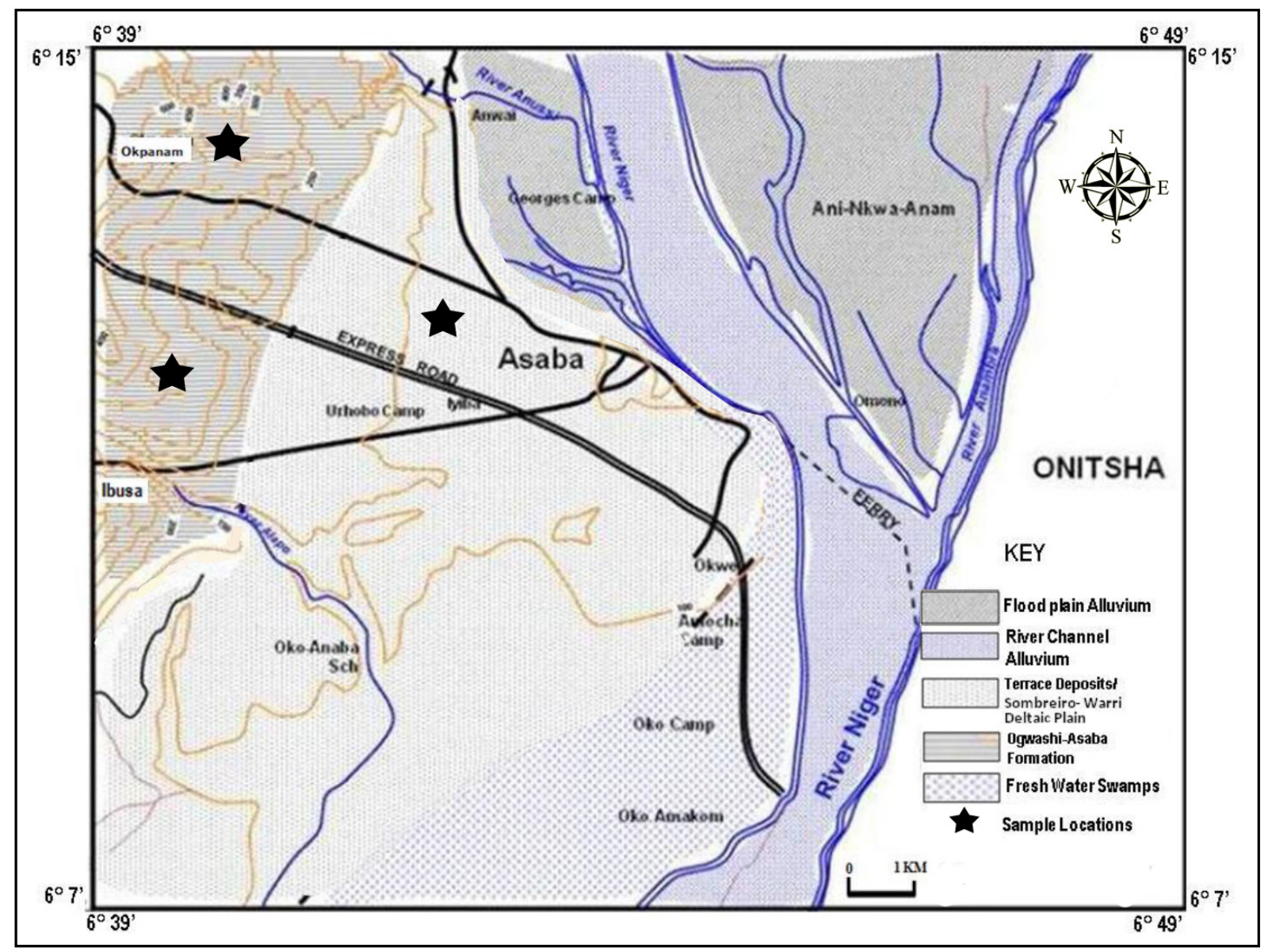

Figure 1. Geological map of Asaba Capital Territory showing sample locations (modified from Akpborie et al. [1]).

\section{Geology and Stratigraphic Setting}

The Cenozoic Niger Delta is situated between the Benue Trough and the equatorial Atlantic Ocean. Its tectonic evolution is related to the development of a triple junction formed as a result of rift faulting of the Precambrian Basement. The triple junction and the Basement blocks aligned in a NE-SW and NW-SE trends are believed to have developed during the continental rifting and separation of Africa from South America [13]. To the east the Niger Delta extends to the Calabar Flank, and bounded by the Oban Massif [14]. Weber [15] noted that the Niger Delta was formed by a set of older and stable mega-tectonic elements (e.g. along the Benin and Calabar Hinge lines). The basin is bounded in the north by the Cretaceous Anambra Basin.

The pro-delta unit of the Niger Delta developed in the northern part of the basin during the Campanian transgression and ended with Paleocene transgression [16]. Formation of the modern delta began during the Eocene. Three major depositional environments that are characteristic of most deltaic environments (marine, mixed and continental) are observable in the Niger Delta [17]. These environments and associated deposits correspond to the Akata, Agbada and Benin Formations. The palaeo-Niger-Benue river system supplied a majority of the ancient deltaic sediments [18]. The basal Akata Formation and the Agbada Formation are only encountered in the subsurface. The contemporaneous outcrop equivalent of the Akata Formation is the Imo Formation; while that of the Agbada Formation is the Ameki Group and the younger overlying Ogwashi-Asaba Formation [17, 19, 20, 21, and 22], Fig. 2, Table 1].

While this paper is concerned mainly with the depositional setting of the sandstones of the Ogwashi-Asaba Formation, brief descriptions of the other formations are also provided in the following sections.

\subsection{Imo Formation}

Whiteman [23] stated that the Imo Formation is the basal unit of the Niger Delta Complex. The outcropping sector of this formation described a concave southward territory stretching from the Benin flank in the west, where it overlies the Nsukka Formation of the Anambra Basin, and widens eastwards. 


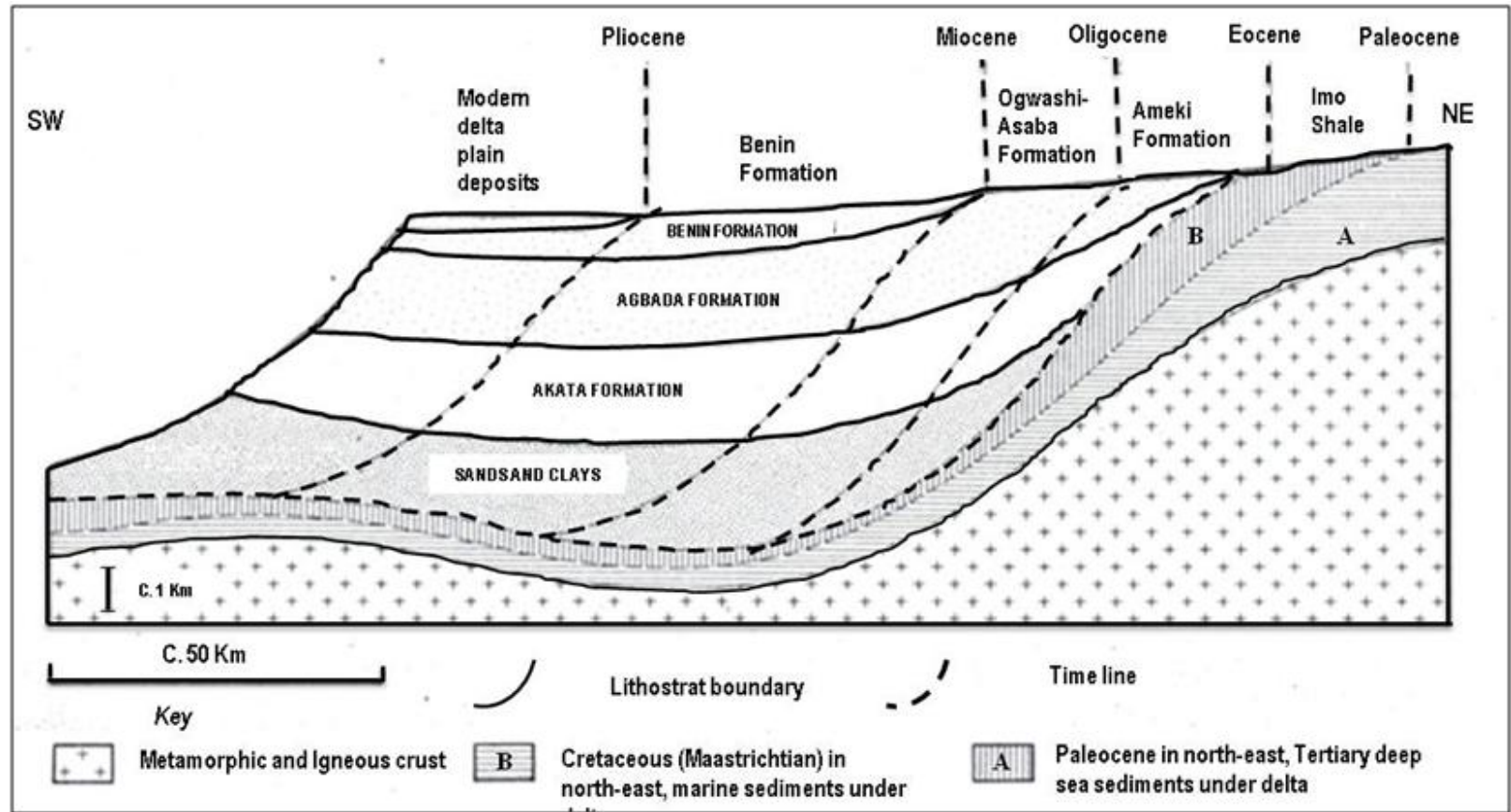

Figure 2. Stratigraphic equivalencies between the outcropping and subsurface Niger Delta (not to scale) (After Wright et al. [26]).

Table 1. Outcropping and subsurface units of the Cenozoic Niger Delta (modified after [21].

\begin{tabular}{|c|c|c|c|c|}
\hline Age_Span[29] & Subsurface section [24] & \multicolumn{2}{|c|}{ Outcrop section [27] } & Characteristics [29] \\
\hline $\begin{array}{l}\text { Oligocene- } \\
\text { Present }\end{array}$ & Benin Formation & \multicolumn{2}{|c|}{ Benin Formation } & $\begin{array}{c}\text { Known also as the Coastal Plain Sands, cross-bedded, } \\
\text { coarse pebbly continental sands, with clay lenses and } \\
\text { lignites, has marine shale breaks with foraminifera, } \\
\text { ostracods and molluscs. }\end{array}$ \\
\hline $\begin{array}{l}\text { Oligocene- } \\
\text { Miocene }\end{array}$ & \multirow{4}{*}{ Agbada Formation } & \multicolumn{2}{|c|}{ Ogwashi-Asaba Fm. } & Clays, silts and sands with thin to thick lignite seams \\
\hline \multirow{3}{*}{$\begin{array}{l}\text { Eocene-Early } \\
\text { Oligocene }\end{array}$} & & \multirow{3}{*}{ Ameki Group } & $\begin{array}{l}\text { Nsugbe } \\
\text { Fm }\end{array}$ & Mainly sands with some conglomerate bands \\
\hline & & & Nanka Fm & $\begin{array}{l}\text { Calcareous clays and silts with thin shelly limestone, } \\
\text { rich in foraminifera }\end{array}$ \\
\hline & & & Ameki Fm & $\begin{array}{l}\text { Calcareous clays and silts with thin shelly limestone, } \\
\text { rich in foraminifera, mainly sands, minor silt and clay } \\
\text { intercalations }\end{array}$ \\
\hline $\begin{array}{l}\text { Paleocene-Early } \\
\text { Eocene }\end{array}$ & Akata Formation & \multicolumn{2}{|c|}{ Imo Formation } & $\begin{array}{c}\text { Blue-grey shales with sand lenses, marls and } \\
\text { fossiliferous limestones, sandstone Members- } \\
\text { Ebenebe, Umuna and Igbaku Sandstones; shales with } \\
\text { foraminifera and ostracods }\end{array}$ \\
\hline
\end{tabular}

\subsection{Ameki Formation}

This formation constitutes the main bulk of Eocene strata overlying the Imo Formation. In south eastern Nigeria, the formation displays rapid lateral facies changes and may locally show shally development or inclusions of white and mottled claystone and sandstone. The Ameki Formation consists of a series of highly fossiliferous grayish-green sandy-clay with calcareous concretions and white clayey sandstones. Reyment [20] recognized two lithological groups: the lower with fine to coarse sandstones and intercalations of calcareous shales and thin shelly limestone; and the upper with coarse, cross-bedded sandstone bands of fine, grey-green sandstone and sandy clay. The thickness may be as much as $1,400 \mathrm{~m}$ in some places.

\subsection{Ogwashi-Asaba Formation}

The Ameki Formation is unconformably overlain by the mostly continental sandstones of the Ogwashi-Asaba and Benin Formations. From the Okitipupa Ridge, this unit occurs in a widening outcrop pattern through Asaba, Onitsha and Uyo to Calabar. The type locality is at Eke-Mgbalingba in Ogwashi-Asaba area. The Ogwashi-Asaba Formation consists of white, blue and pink clays, cross-bedded sands, carbonaceous mudstones, shales and seams of lignite. Beds are horizontal to near horizontal, as such can be termed as undeformed. Pollen data [24] have been used to determine that the lignites originated from tropical and semi-tropical plants consisting mainly of palms. An Oligocene-Miocene upper flood plain environment of deposition has also been inferred [17]. 


\subsection{Benin Formation}

The youngest rock-stratigraphic unit in the Niger Delta basin is the Benin Formation, of possibly Miocene to Recent age [17]. It is composed of continental deposits, including alluvial and upper coastal-plain deposits that are up to $2000 \mathrm{~m}$ thick mostly at the centre of the basin [25].

The base of the Benin Formation has been arbitrarily fixed by the deepest fresh water-bearing sandstone that exhibits high resistivity [26]. This formation occurs across the Niger Delta from Benin-Onitsha area to the present coastline [17].

\section{Material and Methods}

Quarry and outcrop sections where the Ogwashi-Asaba Formation has been recently exposed were logged and representative samples obtained for laboratory analyses. More than thirty rock samples were obtained from quarry sites in Ibusa, Asaba and surrounding areas (Fig. 1) during a geological field mapping exercise. Sandstone samples were obtained from quarry sections at Asaba and Ibusa, while lignite samples were obtained from fresh water spring exposure at Okpanam. About $200 \mathrm{~g}$ of each representative rock samples were collected in polyethylene bags and labeled accordingly (Table 3). A subset of twenty four sandstone samples was subjected to grain size analysis (GSA). Another subset of six representative sandstones samples was analyzed geochemically using fusion and inductively coupled plasma (FUS-ICP) method at the Activation Laboratory, Ontario, Canada.

In the laboratory, the samples for GSA were air-dried, gently disaggregated and homogenized using coning and quartering procedure. Dry sieving of $100 \mathrm{~g}$ of each sample was done using suitable sets of sieves and the electromechanical Ro-tap machine. Textural parameters were computed using the formulae proposed by Folk and Ward [4] and Reineck, and Singh [28]. The graphic mean size (Mz), graphic standard deviation (sorting, $\sigma_{1}$ ), graphic skewness (Sk) and graphic kurtosis $\left(\mathrm{K}_{\mathrm{G}}\right)$ derived from cumulative frequency curves were used for the reconstruction of depositional environments of sediments and sedimentary rocks. Linear Discriminant Functions (LDF) [9] derived from grain size textural parameters were also used to infer depositional settings of sedimentary rocks.

With respect to sample preparation for geochemical analysis by FUS-ICP, the six selected samples were air dried and crushed into powder form using the agate mortar and pestle. Following this the samples were packaged and sent for combined FUS-ICP geochemical analyses at the Activation laboratory, Canada.

\section{Results and Interpretations}

\subsection{Field Observations}

On the basis of field observations, lithological variations and megascopic characteristic of the sedimentary rocks, the exposed section is divisible into five lithofacies (Figures 3 and 4), as follows: (i) friable, massive, whitish to yellowish fine sand lithofacies (ii) thin to thickly bedded, cross and parallel-bedded fine grained sandstone lithofacies, (iii) medium to coarse grained ferruginous sandstone lithofacies (iv) thinly bedded pebble mantled bottom and top lithofacies and (v) lateritic cap lithofacies. The third lithofacies is reddish brown/purple in colour and highly ferruginous sandstone (locally called Ikutegbo) and is often mined for construction purposes. The sandstone facies exhibited a characteristic cross-stratification. Figure 4 shows a representative quarry section of reddish-brown, white and purple coloured sandstone with cross-stratification features as observed in the field within the study area. Also field observation revealed that the upper portion of the Ogwashi-Asaba sandstone is ferruginized in various places with the weathering frontage defined by the degree of infiltration resulting from precipitation. 


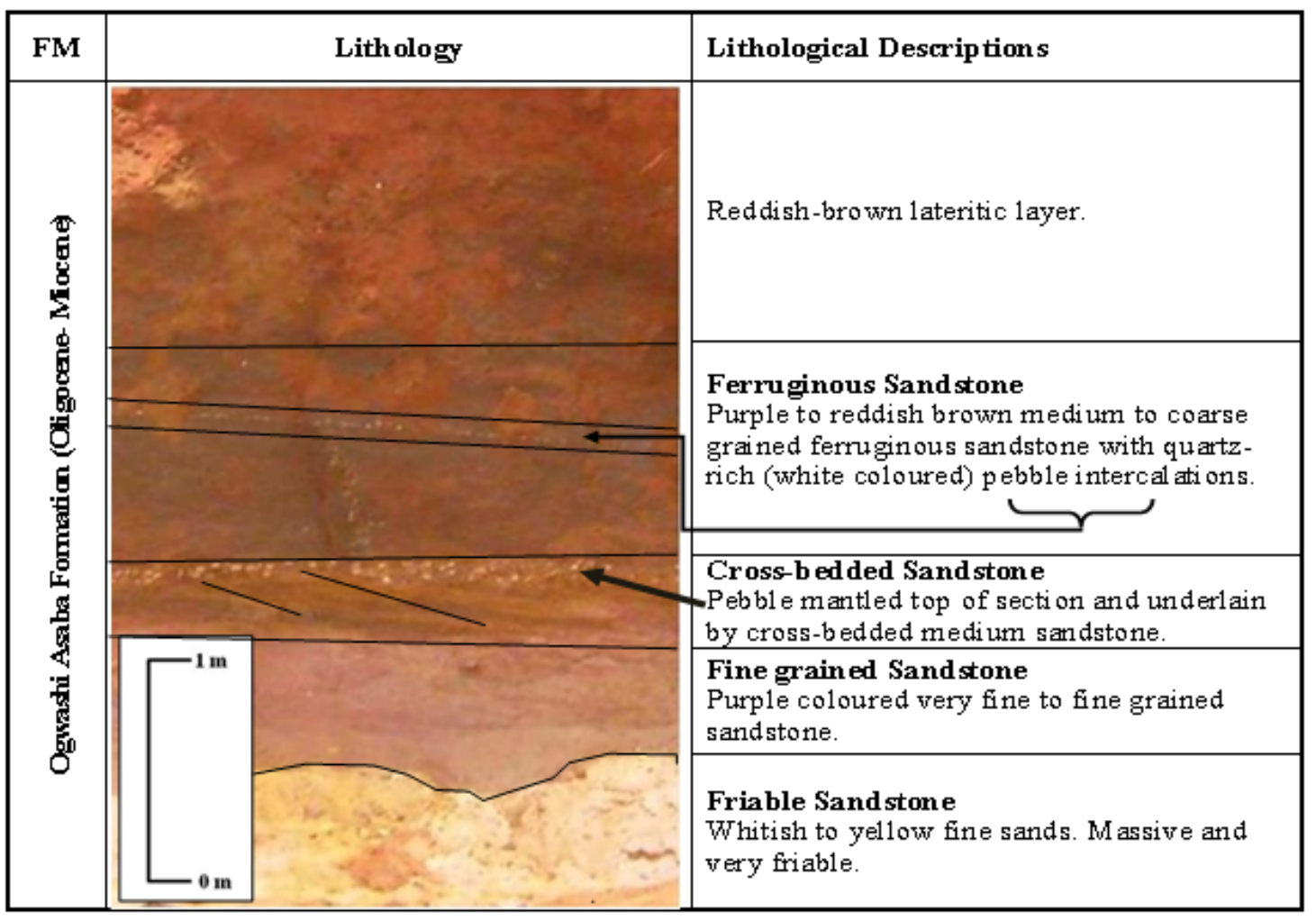

Figure 3. Lithofacies succession on quarry section in the Ogwashi-Asaba Formation

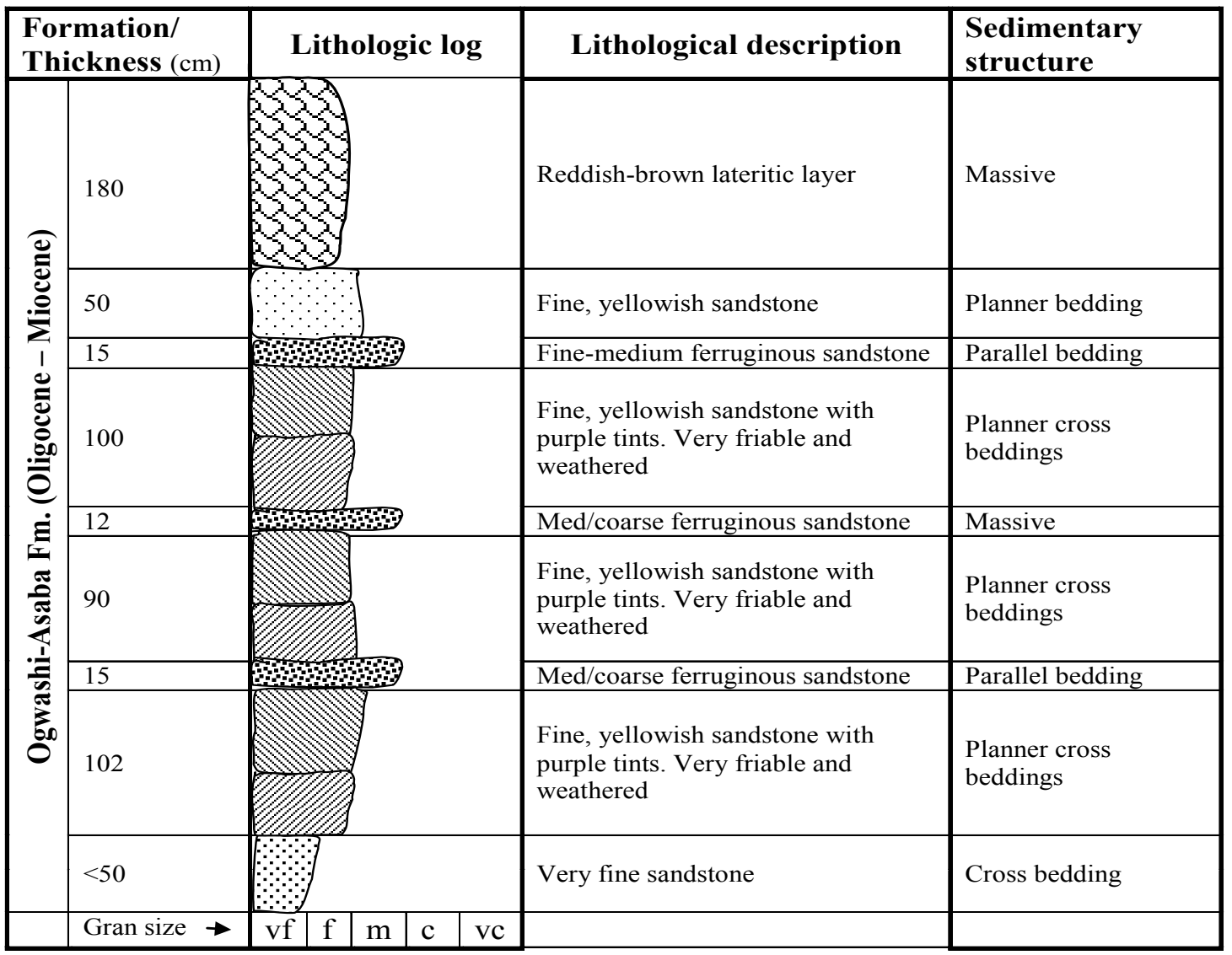

Figure 4. A representative lithologic section of the Ogwashi-Asaba Formation observed at the Ibusa quarry. 
Table 2. Results and interpretation of statistical parameters based on GSA data for the sandstone samples from the Ogwashi-Asaba Formation

\begin{tabular}{|c|c|c|c|c|c|}
\hline $\begin{array}{c}\text { Sample } \\
\text { code }\end{array}$ & $\begin{array}{c}\text { Graphic } \\
\text { mean }(\phi)\end{array}$ & $\begin{array}{c}\text { Graphic } \\
\text { sorting }(\phi)\end{array}$ & $\begin{array}{c}\text { Graphic } \\
\text { skewness (Sk) }\end{array}$ & $\begin{array}{l}\text { Graphic } \\
\text { kurtosis }\end{array}$ & Interpretation \\
\hline Asb_L3b1 & 2.13 & 0.91 & -0.17 & 2.53 & $\begin{array}{c}\begin{array}{c}\text { Fine grained moderately sorted, coarse skewed, very leptokurtic } \\
\text { sandstone. }\end{array} \\
\end{array}$ \\
\hline Asb_L4b2 & 0.58 & 1.16 & 0.31 & 0.99 & Coarse grained, poorly sorted, fine skewed mesokurtic. \\
\hline Asb_L1b2 & 0.68 & 1.15 & 0.32 & 0.94 & Coarse grained, poorly sorted, fine skewed mesokurtic sandstone. \\
\hline Asb_L3b2 & 0.73 & 0.96 & 0.12 & 1.09 & Coarse grained, moderately sorted, fine skewed mesokurtic sandstone \\
\hline Asb_L2b1 & 0.98 & 1.26 & 0.03 & 0.91 & $\begin{array}{c}\text { Coarse grained, poorly sorted, nearly symmetrical, mesokurtic } \\
\text { sandstone. }\end{array}$ \\
\hline Asb_L4b1 & 1.90 & 1.09 & -0.21 & 1.38 & $\begin{array}{c}\text { Medium grained, poorly sorted, nearly symmetrical, leptokurtic } \\
\text { sandstone. }\end{array}$ \\
\hline Asb_L4b4 & 1.57 & 1.43 & -0.05 & 1.05 & $\begin{array}{l}\text { Medium grained, poorly sorted, nearly symmetrical, mesokurtic } \\
\text { sandstone. }\end{array}$ \\
\hline Asb_L1b1 & 1.97 & 1.21 & -0.22 & 1.32 & Medium grained, poorly sorted, coarse skewed, leptokurtic sandstone. \\
\hline Ibs_L1a & 0.9 & 0.93 & -0.12 & 1.43 & $\begin{array}{l}\text { Coarse grained, moderately sorted, coarse skewed and leptokurtic } \\
\text { sandstone. }\end{array}$ \\
\hline Ibs_L1b & 1.35 & 0.79 & 0.03 & 1.65 & $\begin{array}{l}\text { Fine grained, moderately sorted, coarse skewed and very leptokurtic } \\
\text { sandstone. }\end{array}$ \\
\hline Ibs_L1c & 1.53 & 0.97 & -0.38 & 1.90 & $\begin{array}{l}\text { Fine grained, moderately sorted, strongly coarse skewed and very } \\
\text { leptokurtic sandstone. }\end{array}$ \\
\hline Ibs_L1e & 0.38 & 1.28 & -0.30 & 0.82 & $\begin{array}{l}\text { Medium grained poorly sorted, strongly coarse skewed and mesokurtic } \\
\text { sandstone. }\end{array}$ \\
\hline Ibs_L2a & 1.27 & 1.02 & -0.20 & 1.38 & $\begin{array}{c}\text { Fine grained, poorly sorted, coarse skewed and very leptokurtic } \\
\text { sandstone. }\end{array}$ \\
\hline Ibs_L2b & 0.23 & 1.35 & 0.19 & 0.9 & Medium grained, poorly sorted, fine skewed and mesokurtic sandstone \\
\hline Ibs_L2c & 1.48 & 1.42 & -0.32 & 0.99 & $\begin{array}{l}\text { Medium grained, poorly sorted, strongly coarse skewed and } \\
\text { mesokurtic sandstone. }\end{array}$ \\
\hline Ibs_L2e & -0.3 & 1.09 & 0.29 & 1.28 & Coarse grained, poorly sorted, fine skewed and leptokurtic sandstone. \\
\hline Ibs_L3a & 1.37 & 0.89 & -0.08 & 1.21 & $\begin{array}{l}\text { Fine grained, moderately sorted, strongly coarse skewed and } \\
\text { leptokurtic sandstone. }\end{array}$ \\
\hline Ibs_L3b & 0.73 & 1.17 & -0.13 & 0.89 & $\begin{array}{l}\text { Medium grained, poorly sorted, strongly coarse skewed and } \\
\text { platykurtic sandstone. }\end{array}$ \\
\hline Ibs_L3d & 0.23 & 1.52 & -0.49 & 0.79 & Medium grained, poorly sorted, coarse skewed and platykurtic. \\
\hline Ibs_L3e & -0.2 & 1.52 & 0.25 & 0.79 & Coarse grained, poorly sorted, fine skewed and platykurtic sandstone. \\
\hline Ibs_L4a & 1.8 & 0.62 & 0.19 & 1.32 & Fine grained, moderately well sorted, fine skewed and leptokurtic. \\
\hline Ibs_L4b & 0.67 & 1.31 & 0.08 & 0.95 & Medium grained, poorly sorted, coarse skewed and mesokurtic \\
\hline Ibs_L4c & 1.33 & 0.70 & -0.16 & 0.44 & $\begin{array}{l}\text { Fine grained, moderately well sorted, strongly coarse skewed and very } \\
\text { platykurtic sandstone. }\end{array}$ \\
\hline Ibs_L4f & 0.12 & 0.93 & 0.06 & 0.96 & $\begin{array}{l}\text { Medium grained, moderately sorted, coarse skewed and mesokurtic } \\
\text { sandstone. }\end{array}$ \\
\hline Range & $-0.3-2.13$ & $0.62-1.52$ & $-0.49-0.32$ & $0.44-2.53$ & \\
\hline Average & 0.976 & 1.112 & -0.04 & 1.16 & $\begin{array}{c}\text { Medium to coarse grained, poorly sorted, coarse skewed and } \\
\text { leptokurtic sandstone. }\end{array}$ \\
\hline
\end{tabular}

\subsection{Granulometric and Textural Studies}

Textural and statistical indices are presented in Table 2. It is clear from the indices that the sandstones of the Ogwashi-Asaba Formation fall within the fine to coarse-sand category as the graphic mean $(\mathrm{Mz})$ ranges from -0.3 to 2.13 phi In addition, the grain size composition also consists of $29.17 \%$ fine sand, $41.66 \%$ medium sand and $29.17 \%$ coarse sand. Indeed this wide range in grain size is indicative of the variation in the energy of sediment transport and deposition medium. The indices also indicate that the sandstones are poorly to moderately well sorted: inclusive graphic standard deviation (sorting, $\sigma 1$ ), 0.62 to $1.52 \mathrm{phi} ; 8.33 \%$ moderately well sorted, $29.17 \%$ moderately sorted and $62.5 \%$ poorly sorted.

The dominant poorly sorted nature of the sandstones indicate variable current velocities and turbulence during deposition, while the moderately well-sorted sediments indicate smooth, stable currents [5]. Graphic skewness (Sk) ranges from -0.49 to +0.32 (average -0.04 ), implying very fine to coarse skewed arrangement. Skewness variation is as follows: $29.17 \%$ fine skewed, $12.5 \%$ nearly symmetrical, $33.33 \%$ coarse skewed and $25.0 \%$ strongly coarse skewed. Variation in the sign of skewness is due to changing energy conditions of the sedimentary environments [6]. Fluvial sediments are often positively skewed, beach sands show a normal distribution with a slight positive or negative skew, and dune sands are invariably positive [29]. Graphic kurtosis $\left(\mathrm{K}_{\mathrm{G}}\right)$ ranges from 0.44 to 2.53 (average 1.16) and suggests very platykurtic to very leptokurtic. The variation in kurtosis is as follows: $12.5 \%$ platykurtic, $4.16 \%$ very platykurtic, $41.67 \%$ 
mesokurtic, $25.0 \%$ leptokurtic and $16.0 \%$ very leptokurtic. Graphic curves that are more peaked than normal distribution curve are termed leptokurtic; those which are sagged more than normal are said to be platykurtic.

Statistical parameters obtained from textural studies of granular sediments have been successfully applied in sedimentology to reveal the transportation history, sedimentary processes as well as the characteristics of the depositional environments [4, 30, 6, 31, 32, and 33]. Thus the bivariate plots of mean grain size against standard deviation (sorting) (Fig. 5A), Skewness versus standard deviation (Fig. 5B) and simple skewness against standard deviation (Fig. 5C) collectively mean that the sandstone samples from the Ogwashi-Asaba Formation are mostly fluviatile. This view is in conformity with Friedman [6] and Moiola and Weiser [34].

\subsection{Linear Discriminant Functions}

Textural statistical parameters (Mean, Standard deviation, Skewness and Kurtosis) were also used to further discriminate the depositional environment following the discriminant function analysis [9]. Analysis of the data generated from the linear discriminant functions (LDF), Table 3, reveals that the sandstones of the study area were deposited under diverse continental conditions. Table 4 reveals the LDF outputs with Y1 as entirely beach environment, Y2 mostly shallow agitated marine and one sample representing beach and Y3 mostly fluvial deltaic setting and minor shallow marine conditions.

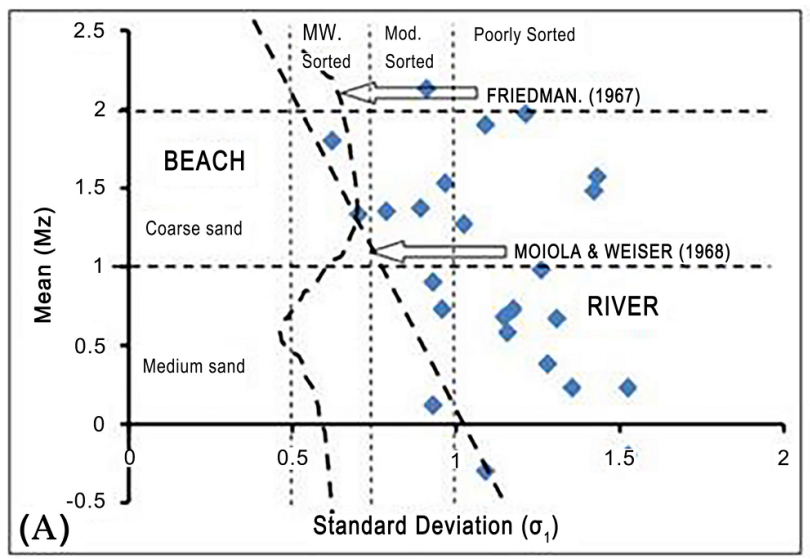

Figure5: Depositional environment discrimination of the sandstones from the Ogwashi-Asaba Formation:

(A) Mean against standard deviation.

(B) Skewness against standard deviation.

(C) Simple skewness measure against simple sorting.

\subsection{Major Element Distribution}

The results of the major elemental distribution for both ferruginized and non-ferruginized sandstone samples from the Ogwashi-Asaba Formation are presented in Table 4, alongside the calculated chemical index of alteration (CIA). Nesbitt and Young [37] define CIA as $\left[\mathrm{Al}_{2} \mathrm{O}_{3} /\left(\mathrm{Al}_{2} \mathrm{O}_{3}+\mathrm{CaO} *+\mathrm{Na}_{2} \mathrm{O}+\right.\right.$ $\mathrm{K}_{2} \mathrm{O}$ )] x 100 , where $\mathrm{CaO}^{*}$ represents $\mathrm{Ca}$ in silicate minerals only [36]. An approximate correction for carbonate content was made by assuming reasonable $\mathrm{Ca} / \mathrm{Na}$ ratios in silicate materials [12]. If the $\mathrm{CaO}$ molecular content is less than that of $\mathrm{Na}_{2} \mathrm{O}$ measured content $\mathrm{CaO}$ content can be used for $\mathrm{CaO}$ * While when $\mathrm{CaO}$ molar content is greater than that of $\mathrm{Na}_{2} \mathrm{O}$, $\mathrm{CaO}^{*}$ is assumed to be equivalent to $\mathrm{Na}_{2} \mathrm{O}$. CIA values between 50 and 60 indicate a low degree of chemical weathering, between 60 and 80 moderate chemical weathering, with values $>80$ indicating extreme chemical weathering [36]. The CIA is also a useful tool for providing a semi-quantitative assessment of paleo-climate in the source area because a large amount of aluminous clay minerals generally forms by intensive chemical weathering under tropical conditions and gives CIA values of 80-100. In contrast, under glacial environments where abrasion is dominant over chemical weathering, common CIA values range from 50 to 70 [17]. Calculated CIA values of the studied samples range between 87.7 and 91.2 (average 89.9; Table 4 and Fig. 6) indicating that the source area may have been subjected to an intense degree of chemical weathering under tropical climatic conditions with abundant rainfall.
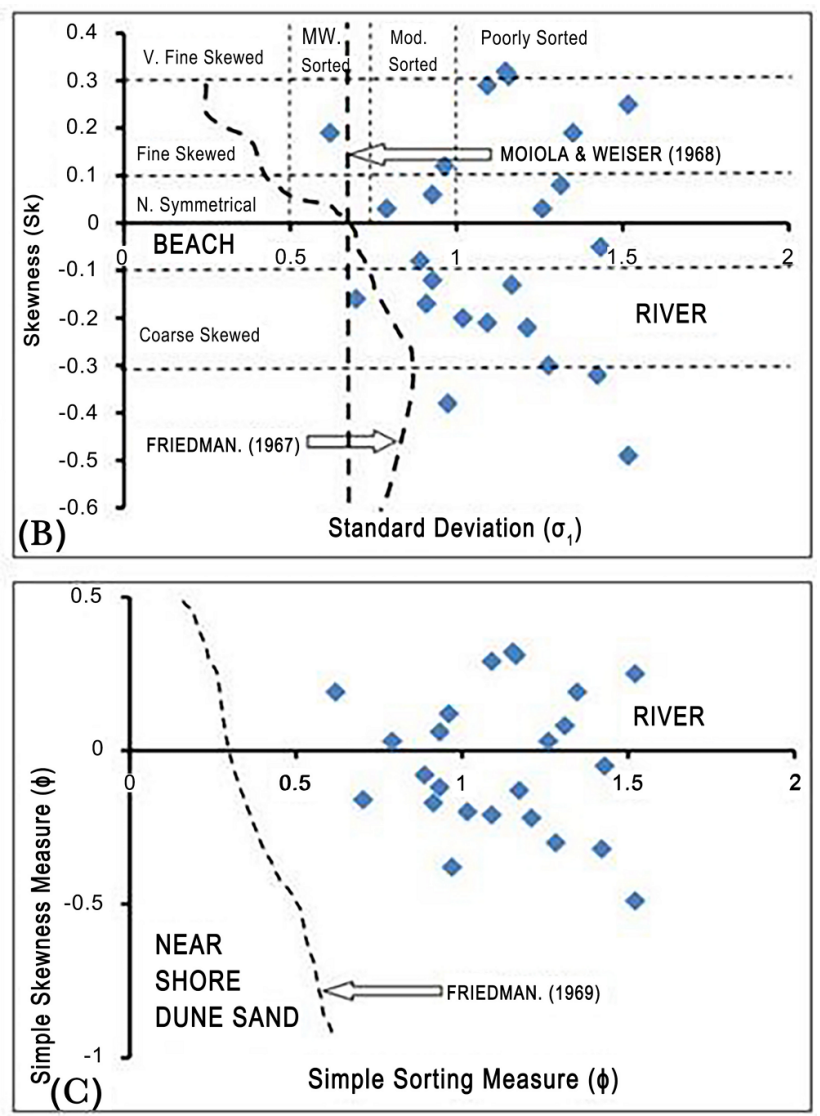
Table 3. Interpretation of processes and environment of deposition by Linear Discriminant Function (9) of sandstones from the Ogwashi-Asaba Formation

\begin{tabular}{|c|c|c|c|c|c|c|c|c|c|c|}
\hline \multirow{2}{*}{ Sample code } & \multirow{2}{*}{$\begin{array}{c}\text { Graphic } \\
\text { Mean }(\mathrm{Mz})\end{array}$} & \multirow{2}{*}{$\begin{array}{c}\text { Graphic } \\
\text { Sorting } \\
\left(\sigma_{1}\right)\end{array}$} & \multirow{2}{*}{$\begin{array}{c}\text { Graphic } \\
\text { Skewness } \\
(\mathrm{Sk})\end{array}$} & \multirow{2}{*}{$\begin{array}{c}\text { Graphic } \\
\text { Kurtosis } \\
\left(\mathrm{K}_{\mathrm{G}}\right)\end{array}$} & \multirow{2}{*}{$\mathrm{Y}_{1}$} & \multirow{2}{*}{$\mathrm{Y}_{2}$} & \multirow{2}{*}{$\mathrm{Y}_{3}$} & \multicolumn{3}{|c|}{ Remarks } \\
\hline & & & & & & & & $\mathrm{Y}_{1}$ & $\mathrm{Y}_{2}$ & $\mathrm{Y}_{3}$ \\
\hline Asb_L3b1 & 2.13 & 0.91 & -0.17 & 2.53 & 3.694 & 131.493 & -5.693 & Beach & Shallow agitated marine & Shallow marine \\
\hline Asb_L4b2 & 0.58 & 1.16 & 0.31 & 0.99 & 5.350 & 121.430 & -13.092 & Beach & Shallow agitated marine & Fluvial (Deltaic) \\
\hline Asb_L1b2 & 0.68 & 1.15 & 0.32 & 0.94 & 4.731 & 120.733 & -12.912 & Beach & Shallow agitated marine & Fluvial (Deltaic) \\
\hline Asb_L3b2 & 0.73 & 0.96 & 0.12 & 1.09 & 3.951 & 94.327 & -8.400 & Beach & Shallow agitated marine & Fluvial (Deltaic) \\
\hline Asb_L2b1 & 0.98 & 1.26 & 0.03 & 0.91 & 5.150 & 137.042 & -13.731 & Beach & Shallow agitated marine & Fluvial (Deltaic) \\
\hline Asb_L4b1 & 1.90 & 1.09 & -0.21 & 1.38 & 2.350 & 129.544 & -8.772 & Beach & Shallow agitated marine & Fluvial (Deltaic) \\
\hline Asb_L4b4 & 1.57 & 1.43 & -0.05 & 1.05 & 5.339 & 177.469 & -17.171 & Beach & Shallow agitated marine & Fluvial (Deltaic) \\
\hline Asb_L1b1 & 1.97 & 1.21 & -0.22 & 1.32 & 2.956 & 147.484 & -11.124 & Beach & Shallow agitated marine & Fluvial (Deltaic) \\
\hline Ibs_L1a & 0.9 & 0.93 & -0.12 & 1.43 & 4.691 & 95.208 & -6.664 & Beach & Shallow agitated marine & Shallow marine \\
\hline Ibs_L1b & 1.35 & 0.79 & 0.03 & 1.65 & 2.567 & 93.217 & -5.150 & Beach & Shallow agitated marine & Shallow marine \\
\hline Ibs_L1c & 1.53 & 0.97 & -0.38 & 1.90 & 4.727 & 114.053 & -5.855 & Beach & Shallow agitated marine & Shallow marine \\
\hline Ibs_L1e & 0.38 & 1.28 & -0.30 & 0.82 & 7.884 & 123.348 & -12.737 & Beach & Shallow agitated marine & Fluvial (Deltaic) \\
\hline Ibs_L2a & 1.27 & 1.02 & -0.20 & 1.38 & 4.031 & 110.158 & -7.707 & Beach & Shallow agitated marine & Fluvial (Deltaic) \\
\hline Ibs_L2b & 0.23 & 1.35 & 0.19 & 0.9 & 8.333 & 143.449 & -16.787 & Beach & Shallow agitated marine & Fluvial (Deltaic) \\
\hline Ibs_L2c & 1.48 & 1.42 & -0.32 & 0.99 & 5.929 & 168.188 & 15.628 & Beach & Shallow agitated marine & Fluvial (Deltaic) \\
\hline Ibs_L2e & -0.3 & 1.09 & 0.29 & 1.28 & 8.852 & 102.310 & -11.851 & Beach & Shallow agitated marine & Fluvial (Deltaic) \\
\hline Ibs_L3a & 1.37 & 0.89 & -0.08 & 1.21 & 1.976 & 94.435 & -6.099 & Beach & Shallow agitated marine & Shallow marine \\
\hline Ibs_L3b & 0.73 & 1.17 & -0.13 & 0.89 & 5.503 & 115.491 & -11.105 & Beach & Shallow agitated marine & Fluvial (Deltaic) \\
\hline Ibs_L3d & 0.23 & 1.52 & -0.49 & 0.79 & 11.209 & 161.161 & -17.739 & Beach & Shallow agitated marine & Fluvial (Deltaic) \\
\hline Ibs_L3e & -0.2 & 1.52 & 0.25 & 0.79 & 11.206 & 167.828 & -21.482 & Beach & Shallow agitated marine & Fluvial (Deltaic) \\
\hline Ibs_L4a & 1.8 & 0.62 & 0.19 & 1.32 & -1.286 & 81.301 & -3.720 & Beach & Shallow agitated marine & Shallow marine \\
\hline Ibs_L4b & 0.67 & 1.31 & 0.08 & 0.95 & 6.753 & 142.279 & -15.188 & Beach & Shallow agitated marine & Fluvial (Deltaic) \\
\hline Ibs_L4c & 1.33 & 0.70 & -0.16 & 0.44 & -1.231 & 58.261 & -3.109 & Beach & Beach & Shallow marine \\
\hline Ibs_L4f & 0.12 & 0.93 & 0.06 & 0.96 & 5.638 & 77.561 & -7.790 & Beach & Shallow agitated marine & Fluvial (Deltaic) \\
\hline \multicolumn{11}{|c|}{ Formulas of Linear Discriminant Functions (LDF) (after Sahu[9]) } \\
\hline \multicolumn{2}{|c|}{ Aeolian or Beach } & \multicolumn{9}{|c|}{$\begin{array}{l}\mathrm{Y}_{1}=-3.5688 . \mathrm{Mz}+3.7016 . \sigma_{1}^{2}-2.0766 . \mathrm{Sk}+3.1135 . \mathrm{K}_{\mathrm{G}} \\
\text { If } \mathrm{Y}_{1}>-2.7411=\text { Beach ; if } \mathrm{Y}_{1}<-2.7411=\text { Aeolian }\end{array}$} \\
\hline \multicolumn{2}{|c|}{ Backshore or sub-tidal } & \multicolumn{9}{|c|}{$\begin{array}{c}\mathrm{Y}_{2}=15.6534 . \mathrm{Mz}+65.7091 . \sigma_{1}^{2}+18.1071 . \mathrm{Sk}+18.50435 . \mathrm{K}_{\mathrm{G}} \\
\text { If } \mathrm{Y}_{2}=\leq 65.365=\text { Beach (Back shore); if } \mathrm{Y}_{2}>65.365=\text { Shallow agitated marine }\end{array}$} \\
\hline \multicolumn{2}{|c|}{$\begin{array}{l}\text { Shallow marine or fluvial } \\
\text { (deltaic) }\end{array}$} & \multicolumn{9}{|c|}{$\begin{array}{l}\mathrm{Y}_{3}=0.2852 . \mathrm{Mz}-8.7604 . \sigma_{1}{ }^{2}-4.8932 . \mathrm{Sk}+0.0482 \mathrm{~K}_{\mathrm{G}} \\
-7.4190=\text { Fluvial (deltaic); if } \mathrm{Y}_{3}>-7.4190=\text { Shallov }\end{array}$} \\
\hline
\end{tabular}


Table 4. Results of the major elements analyses alongside weathering indices

\begin{tabular}{|c|c|c|c|c|c|c|}
\hline Rock type & \multicolumn{3}{|c|}{ Ferruginized sandstones } & \multicolumn{3}{|c|}{ Non-ferruginized sandstones } \\
\hline $\begin{array}{l}\text { Sample code/ major } \\
\text { elements (wt \%) }\end{array}$ & IBS_L2E & IBS_L3E & IBS_L2B & IBS_L1C & IBS_L2A & IBS_L3B \\
\hline $\mathrm{SiO}_{2}$ & 71.42 & 76.57 & 78.51 & 87.48 & 90.84 & 92.76 \\
\hline $\mathrm{TiO}_{2}$ & 0.294 & 0.033 & 0.041 & 0.119 & 0.177 & 0.098 \\
\hline $\mathrm{Al}_{2} \mathrm{O}_{3}$ & 1.59 & 1.13 & 1.46 & 1.13 & 1.85 & 1.38 \\
\hline $\mathrm{Fe}_{2} \mathrm{O}_{3}$ * & 21.42 & 19.12 & 16.79 & 9.48 & 4.84 & 3.63 \\
\hline $\mathrm{MnO}$ & 0.025 & 0.012 & 0.014 & 0.015 & 0.01 & 0.011 \\
\hline $\mathrm{MgO}$ & 0.03 & 0.02 & 0.02 & 0.01 & 0.01 & 0.02 \\
\hline $\mathrm{CaO}$ & 0.02 & 0.02 & 0.09 & 0.02 & 0.02 & 0.44 \\
\hline $\mathrm{Na}_{2} \mathrm{O}$ & 0.05 & 0.04 & 0.05 & 0.03 & 0.04 & 0.05 \\
\hline $\mathrm{K}_{2} \mathrm{O}$ & 0.03 & 0.04 & 0.03 & 0.03 & 0.03 & 0.03 \\
\hline $\mathrm{P}_{2} \mathrm{O}_{5}$ & 0.38 & 0.28 & 0.25 & 0.18 & 0.1 & 0.03 \\
\hline LOI & 3.52 & 3.02 & 2.84 & 1.62 & 1.32 & 1.69 \\
\hline Total & 98.78 & 100.3 & 100.1 & 100.1 & 99.24 & 100.1 \\
\hline $\mathrm{MgO}+\mathrm{Fe}_{2} \mathrm{O}_{3} *$ & 21.45 & 19.14 & 16.81 & 9.49 & 4.85 & 3.65 \\
\hline $\mathrm{Fe}_{2} \mathrm{O}_{3} * / \mathrm{K}_{2} \mathrm{O}$ & 714 & 478 & 559.7 & 316 & 161.3 & 121 \\
\hline $\mathrm{CaO} *+\mathrm{Na}_{2} \mathrm{O}$ & 0.0012 & 0.0010 & 0.0016 & 0.0009 & 0.0010 & 0.0016 \\
\hline $\mathrm{Al}_{2} \mathrm{O}_{3} / \mathrm{TiO}_{2}$ & 5.408 & 34.242 & 35.609 & 9.496 & 10.452 & 14.082 \\
\hline $\mathrm{K}_{2} \mathrm{O} / \mathrm{Na}_{2} \mathrm{O}$ & 0.6 & 1.0 & 0.6 & 1.0 & 0.75 & 0.6 \\
\hline $\mathrm{SiO}_{2} / \mathrm{Al}_{2} \mathrm{O}_{3}$ & 44.92 & 67.76 & 53.77 & 77.42 & 49.10 & 67.22 \\
\hline \multicolumn{7}{|l|}{ Moles } \\
\hline $\mathrm{SiO}_{2}$ & 1.1886 & 1.2743 & 1.3065 & 1.4558 & 1.5117 & 1.5437 \\
\hline $\mathrm{Al}_{2} \mathrm{O}_{3}$ & 0.0156 & 0.0111 & 0.0143 & 0.0111 & 0.0181 & 0.0135 \\
\hline $\mathrm{CaO}^{*}$ & 0.0004 & 0.0004 & 0.0008 & 0.0004 & 0.0004 & 0.0008 \\
\hline $\mathrm{Na}_{2} \mathrm{O}$ & 0.0008 & 0.0006 & 0.0008 & 0.0005 & 0.0006 & 0.0008 \\
\hline $\mathrm{K}_{2} \mathrm{O}$ & 0.0003 & 0.0004 & 0.0003 & 0.0003 & 0.0003 & 0.0003 \\
\hline CIA & 91.228 & 88.800 & 88.272 & 90.244 & 93.299 & 87.663 \\
\hline
\end{tabular}

As shown in Table 4 , the analyzed samples are dominated by silica with 71.42 to 92.72 wt. $\% \mathrm{SiO}_{2}$, while other major oxides are generally below 1.0 wt. \% with exception of $\mathrm{Al}_{2} \mathrm{O}_{3}$ (1.13 to 1.85 wt.\%) and $\mathrm{Fe}_{2} \mathrm{O}_{3}$ (3.63 to 21.42 wt.\%) for both ferruginized and non-ferruginized samples. The ferruginized samples possess almost similar chemical trends and exhibit high concentrations of $\mathrm{Al}_{2} \mathrm{O}_{3}$ (1.13-1.59 wt. \%) and $\mathrm{Fe}_{2} \mathrm{O}_{3}$ (16.79 to $21.42 \mathrm{wt} \%$ ), which are clear indications of weathering processes. This is also confirmed by the $\mathrm{Si} / \mathrm{Al}$ ratio of 44.92 to 77.42 .

With respect to the ternary plots of the molecular proportions of the chemical composition using $\mathrm{Al}_{2} \mathrm{O}_{3}-$ $\mathrm{CaO}^{*}+\mathrm{Na}_{2} \mathrm{O}-\mathrm{K}_{2} \mathrm{O}$ as presented in Figure 6, it can be observed that all the samples lie towards the $\mathrm{Al}_{2} \mathrm{O}_{3}$ corner similar to that of $\mathrm{SiO}_{2}$ thus indicating severe depletion of the $\mathrm{CaO}^{*}+\mathrm{Na}_{2} \mathrm{O}$ and $\mathrm{K}_{2} \mathrm{O}$. As indicated in Figure 6, the sandstone samples of the Ogwashi-Asaba plot at the $\mathrm{Al}_{2} \mathrm{O}_{3}$ corner (also similar to $\mathrm{SiO}_{2}$ ). This suggests intense primary weathering processes and removal of feldspars and other labile components that characterized the primary source rock materials.

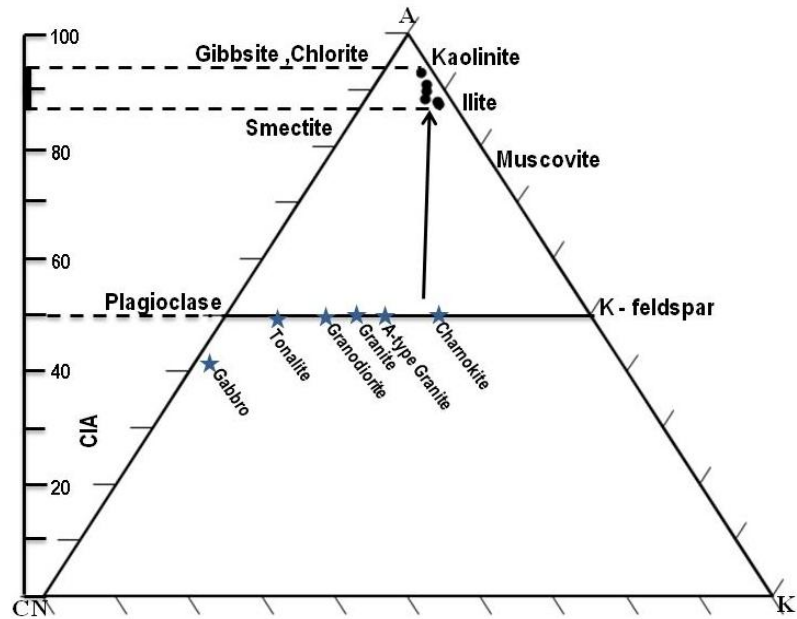

Figure 6. Chemical Index of Alteration (CIA) ternary plot of molecular proportions of $\mathrm{Al}_{2} \mathrm{O}_{3}-\left(\mathrm{CaO} *+\mathrm{Na}_{2} \mathrm{O}\right)-\mathrm{K}_{2} \mathrm{O}$ for sandstones from the Ogwashi-Asaba Formation. The solid arrow points to the actual weathering trend for the samples. Note A represents $\mathrm{Al}_{2} \mathrm{O}_{3}, \mathrm{CN}=\left(\mathrm{CaO}^{*}+\mathrm{Na}_{2} \mathrm{O}\right)$ and $\mathrm{K}=\mathrm{K}_{2} \mathrm{O}$ (After Nesbit and Young [11] and Fedo et al. [46]). 


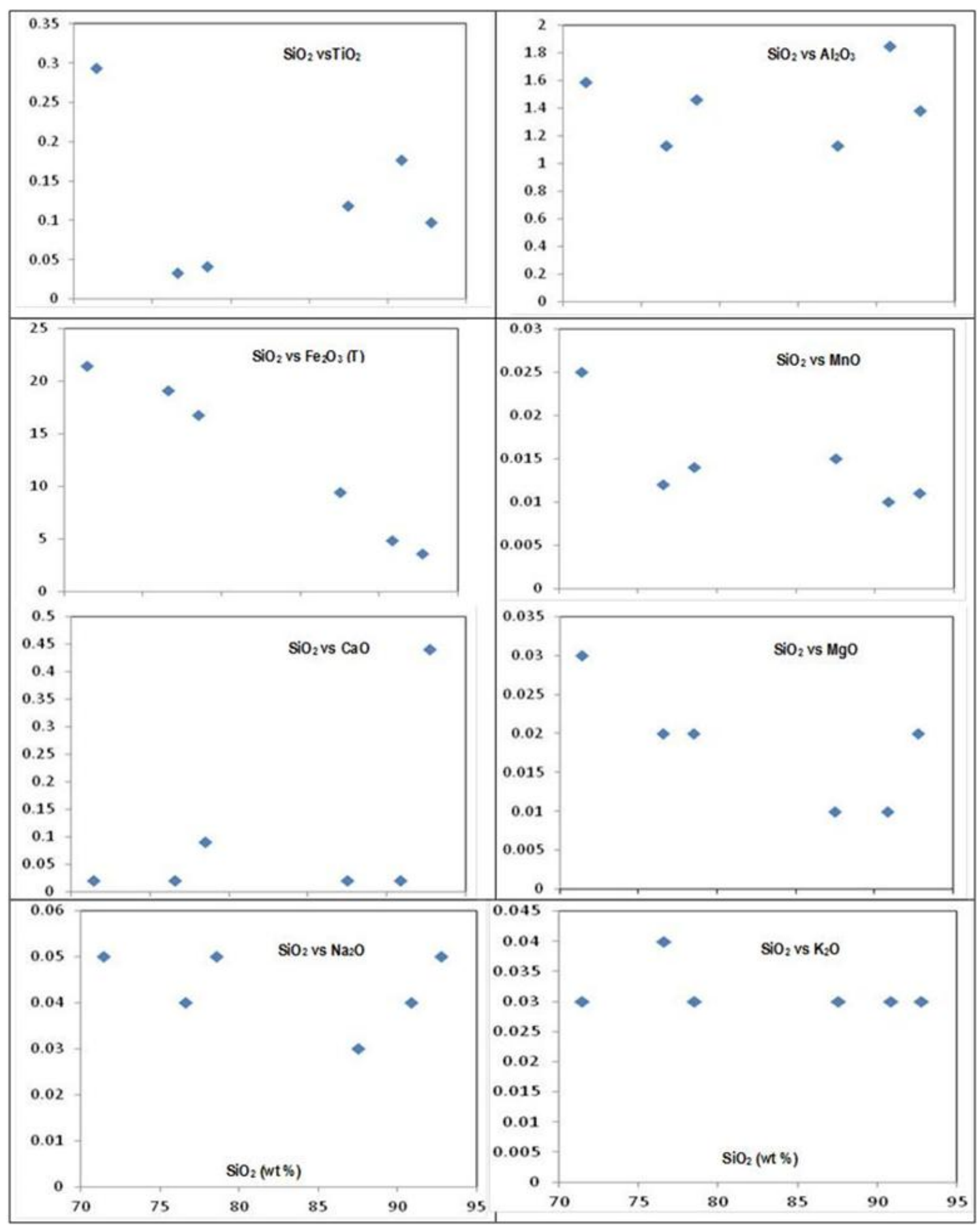

Figure 7. Harker diagrams showing variation between selected major elements (on y-axis in \%) and $\mathrm{SiO}_{2}$ (on $\mathrm{x}$-axis in \%) for sandstone suites of the Ogwashi-Asaba Formation.

Harker diagrams were also used to compare the abundances of the major element oxides (in weight \%) along a common x-axis, namely, $\mathrm{SiO}_{2}$ (Fig. 7). As it was expected, there is a negative correlation with silica as shown in the in Harker diagrams (cross plots of $\mathrm{SiO}_{2}$ (wt. \%) versus $\mathrm{TiO}_{2}$, $\mathrm{Al}_{2} \mathrm{O}_{3}, \mathrm{Fe}_{2} \mathrm{O}_{3}, \mathrm{MnO}, \mathrm{CaO}, \mathrm{MgO}, \mathrm{Na}_{2} \mathrm{O}$, and $\mathrm{K}_{2} \mathrm{O}$ respectively (Fig.7). These generally demonstrate the influence of weathering processes through enrichment of silica, partial enrichment of $\mathrm{Fe}$ (for ferruginized samples) and depletion of
$\mathrm{Ti}, \mathrm{Mn}, \mathrm{Ca}, \mathrm{Mg}, \mathrm{Na}$ and $\mathrm{K}_{2} \mathrm{O}$ with increasing weathering and maturity of the sandstones. The negative correlation between $\mathrm{SiO}_{2}$ and $\mathrm{Al}_{2} \mathrm{O}_{3}$ is also an indication of the fact that most of the silica is present as quartz grains. It can therefore be suggested that the depletion of all other major elements at the expense silica in the Ogwashi-Asaba sandstone is probably related to the removal of ferromagnesian minerals and feldspars through reworking and transportation of the source materials by sedimentary processes. 


\section{Discussion and Inferences}

\subsection{Depositional Setting: Evidence from Field and Textural Characteristics}

Colours of the various lithologies also provide important field evidence of depositional setting. Generally, the colour of sedimentary rocks provides useful clues to the depositional environment. Red (often more of a maroon or a pink), and brown, purple, or orange colouration in sedimentary rocks indicates the presence of iron oxides. In well-oxygenated continental sedimentary environments, the iron in the sediments is oxidized to form hematite or ferric iron oxide $\left(\mathrm{Fe}_{2} \mathrm{O}_{3}\right)$, which colours the sediment red, brown, or purple such as that which is obtainable in the study area. The reddish-brown colourations of the beds in the Ogwashi Asaba Formation as observed in the study area typically indicate deposition in continental (or transitional) sedimentary environments such as flood plains, alluvial fans, and deltas [28].

Interrelationship between textural distribution and depositional environments and/or processes has been used successfully to identify the depositional environments and recognize operative processes of sedimentation of ancient terrigenous deposits $[6,24]$. Thus while the bivariate size parameter diagrams, Figure 5 are indicative of a fluviatile environment of deposition, the linear discriminant functions provide further evidence of the precise operative processes in a fluvial system. The samples from the Ogwashi-Asaba thus yielded LDF's, Table 3, that are suggestive of fluvial operative processes which vary from fluvial deltaic to beach and shallow agitated marine to shallow marine. This is represents a mixed environment typical of fluvio-deltaic to shallow marine depositional settings. This is in agreement with the suggested paralic delta front facies model for the Agbada Formation [17] as well as the universally accepted models of growth and development of the Niger Delta Basin.

\subsection{Geochemistry and Weathering}

Calculated CIA values of the studied samples range between 87.7 and 91.2 (average 89.9; Table 4 and Fig. 6) indicating that the source area may have been subjected to intense chemical weathering under tropical climatic conditions with abundant rainfall [37]

\section{Conclusions}

Sandstones from the study area were studied texturally and geochemically. Sandy sediments are mostly medium to coarse grained, moderately well-sorted to poorly sorted, fine to coarse skewed and platykurtic to very leptokurtic. Statistical analysis of the grain size parameters are used to interpret depositional environment and describe the changes in the environmental setting of deposition. From the bivariate plots and linear discriminant function it is obvious that most of the sediments were fluvially transported and deposited under fluvio-deltaic to shallow marine environment. A combination of fluvial and beach processes by a near shore whirlpool agitating turbidity action of water likely prevailed during deposition. Geochemical data have helped in ascertaining the weathering trends of the sediments. The chemical index of alteration (CIA) has been used to quantify the degree of weathering of stream sediments and terraces samples. CIA values range between 87.7 and 93.3 on a scale of $0-100$, indicating a high degree of alteration.

\section{REFERENCES}

[1] I. A. Akpoborie, Nfor, N.A., Etobro, A.A.I. and Odagwe, S. Aspects of the Geology and groundwater conditions of Asaba, Nigeria. Archives of Applied Sci. Res. Vol.3 no.2, 537 - 550, 2011.

[2] J.E. Ogala. The geochemistry of lignite from the Neogene Ogwashi-Asaba Formation, Niger Delta Basin, southern Nigeria. Earth Sci. Res. Jour. vol.16 no.2, 151 - 164, 2012.

[3] C. Bassey and Eminue, O. Petrographic and stratigraphic analyses of Palaeogene Ogwashi-Asaba formation, Anambra Basin, Nigeria. NAFTA vol.7-8, 247-254, 2012.

[4] R.L. Folk and Ward, W.C., 1957. Brazo river bar: A study of the significance of grain size parameters. Jour. Sed. Geol. Vol.27, 3-26, 1957.

[5] E.J. Amaral and Pryor, W.R. Depositional environments of the St. Peter sandstone deduced by textural analysis. Jour. Sed. Petrol. Vol.47, 32-52, 1977.

[6] G.M. Friedman. Dynamic process and statistical parameters compared for size frequency distribution of beach and river sands. Jour. Sed. Petrol. Vol.37, 327-354, 1967.

[7] G.M. Friedman. Distinction between dune, beach and river sands from their textural characteristics. Jour. Sed. Petrol., Vol.3, no.14, 514-52, 1961.

[8] G.S. Visher. Grain size distributions and depositional processes. Jour. Sed. Petrol. vol.39, 1074-1106, 1969.

[9] B.K. Sahu. Depositional Mechanism from the size analysis of Sediments. Jour. Sed. Petrol. Vol. 34, no.1, 73 - 83, 1964.

[10] S.R. Taylor and McLennan, S.M. The continental crust: its composition and evolution, Oxford, Blackwell, 1985.

[11] H.W. Nesbitt and Young, G.M. Formation and diagenesis of weathering profiles. The Jour. of Geol. vol.97, 129-147, 1989.

[12] S.M. McLennan, Hemming, S., McDaniel, D.K. and Hanson, G.N. Geochemical approaches to sedimentation, provenance and tectonics, In: Johnsson, M.J., Basu, A. (eds.): Geologic. Soc. Ameri., Spec. Papers, vol. 285, 21-40, 1993.

[13] P. Lehner and De Ruiter, P. A. C. Structural history of Atlantic margin of Africa. Ameri. Assoc. Petrol. Geol. Bulletin, vol. 61 961-981, 1977.

[14] R.C. Murat. Stratigraphy and Paleogeography of the Cretaceous and lower Tertiary in southern Nigeria. In: T.J.F. Dessauvagie and A.J. Whiteman (.eds), African Geology, 
University of Ibadan Press, Nigeria, 1972.

[15] K.J. Weber. Sedimentological aspects of oil fields in the Niger Delta. Geol.en Mijnb vol. 50, 559-576, 1971.

[16] C.A. Kogbe. Palaeogeographic history of Nigeria from Albian times. In: Kogbe, C.A. (ed.), Geology of Nigeria. Rock View (Nig.) Ltd, Jos, 257-276, 1989.

[17] K.C. Short and Stäuble. Outline Geology of the Niger Delta. Ameri. Assoc. Petrol. Geologists Bulletin, vol. 51, no.5, 761-779, 1967.

[18] K. Burke. Longshore drift, submarine canyons, and submarine fans in development of Niger Delta. Ameri. Assoc.Petrol. Geologists Bulletin, vol. 56, 1975-1983, 1972.

[19] J.B. Wright, Hastings, D.A., Jones, W.B. and Williams, H.R. Geology and Mineral Resources of West Africa. George Allen and Unwin, London, 1985.

[20] R.A. Reyment. Aspects of Geology of Nigeria. University of Ibadan press, Nigeria, 1965.

[21] P. Maron. Stratigraphical aspects of the Niger Delta. Jour. Min. and Geol. Vol. 4, nos.1\&2, 3-12, 1969.

[22] C.S. Nwajide. Geology of Nigeria's Sedimentary Basins.CSS Bookshop Ltd., Lagos, 2013.

[23] A.J. Whiteman, A.J. Nigeria: Its Petroleum Geology, Resources and Potential. Graham and Trotman, London, 1982.

[24] C.N. Okezie and Onuogu, S.A. The lignites of southeastern Nigeria. Geol. Surv. Nigeria Occasional Paper vol. 10, 1-28, 1985.

[25] A.A. Avbovbo. Tertiary lithostratigraphy of the Niger Delta. Amer. Assoc. Petroleum Geologists Bulletin, vol. 62, 295300, 1978.

[26] H. Doust and Omatsola, E. Niger Delta: In Divergent/Passive Margins, Edwards, J. D. and Santogrossi, P.(eds). Amer. Assoc. Petrol. Geologists Memoir vol. 48, Tulsa Oklahoma, 210-238, 1990.

[27] E.F. McBride. Significance of colour in red, green, purple, olive brown and grey beds of Difunta Group, Northeastern
Mexico. Jour. of Sed. Petrol. vol. 44 760-773, 1974.

[28] H.E, Reineck, and Singh, I.B. Depositional Sedimentary Environments: with reference to terrigenous clastics $\left(2^{\text {nd }}\right.$ ed $)$. Springer-Verlag, Berlin, Heidelberg, New York, 543, 1980.

[29] G.M. Friedman. Differences in size distributions of populations of particles among sands of various origins. Sedimentology vol. 26, 3-32, 1979.

[30] R.L. Folk..Petrology of Sedimentary Rocks $2^{\text {nd }}$ ed., Hemphill Press, Austin, TX, 1974.

[31] G.M. Friedman, G.M. Differences in size distribution of populations of particles among sands of various origins. Sedimentology vol. 26, 3-32, 1969.

[32] R.O. Olugbemiro and Nwajide, C.S. Grain-size distribution and particle morphogenesis as signatures of depositional environments of Cretaceous (non-ferruginous) facies in the Bida Basin, Nigeria. Jour. Min. Geol. Vol.33 no.2, 89-101, 1997.

[33] O.I. Ejeh, Etobro, A.A.I. and Adaikpoh, E.O. Pattern of Geochemical and Sedimentological Variability of the Albian to Cenomanian Upper Bima Sandstone, Benue Trough, Nigeria: Implications on Tectonic provenance and Source Area Weathering. Jour. Environment and Earth Sci., vol. 3 no.14, 170-184, 2013.

[34] R.J. Moiola and Weiser, D. Textural parameters: An evaluation. Jour. Sed. Petrol., vol.38 no1, 45-53, 1968.

[35] C.M. Fedo, Nesbitt, H.W. and Young, G.M. Unravelling the effects of potassium metasomatism in sedimentary rocks and paleosols, with implications for palaeo-weathering conditions and provenance. Geology vol. 23, 921-924, 1995.

[36] C.M. Fedo, Young, G.M., Nesbitt, H.W. and Hanchar, J.M. Potassic and sodic metasomatism in the Southern Province of the Canadian Shield: evidence from the Paleoproterozoic Serpent Formation, Huronian Supergroup, Canada. Precambrian Research, vol. 84, 17-36, 1997.

[37] H.W. Nesbitt and Young, G.M. Prediction of some weathering trends of plutonic and volcanic rocks based on thermodynamic and kinetic considerations. Geochimica et Cosmochimica Acta, vol. 48, 1523-1534, 1984. 